DOI: $10.34185 / 1991-7848.2021 .01 .13$

UDC: 621.365 .22

S. Timoshenko, E. Nemtsev, M. Gubinski ${ }^{13}$

\title{
ENERGY EFFICIENT WATER-COOLED ELEMENTS FOR FOUNDRY CLASS ELECTRIC ARC STEELMAKING FURNACES
}

Low energy efficiency of foundry class electric arc steelmaking furnaces (EAF) mainly is caused by heat loss by massive lining during forced downtime. A low-power transformer doesn't allow, in the conditions of classical technology, practice of traditional water-cooled elements in order to replace partially the lining, what determines increased refractory consumption. The aim is energy and refractory savings. On the basis of numerical modeling of heat exchange by radiation in the EAF working space, taking into account capacity, bath shape factor, duration of technological period of heat, a multiple regression equation for power of heat loss with cooling water was obtained. Three-row water-cooled wall panels with a spatial structure are elaborated, which provide a decrease in heat loss by $14 \%$, in comparison with two-row ones. Estimates of optimal relative cooled surface of the EAF working space, providing refractory savings up to 25-30\%, are substantiated.

Keywords: foundry class electric arc furnace, water-cooled elements, energy efficiency.

\section{Introduction}

Possibility of a wide choice of original charge and variation of oxidation potential in melting process makes the electric arc furnace (EAF) a general-purpose unit in foundry shops of engineering industry

Energy-intensive classical technology with at usually low specific power of the transformer, irregular operation with forced downtime predetermine a much lower, in comparison with "large" metallurgy, energy efficiency of foundry class furnaces [1, 2]. Flat and shallow steelmaking bath of the EAF enhances the problem due to increased heat loss by radiation in the conditions of long refining period.

Application of traditional for EAF of "large" metallurgy water-cooled elements (WCE) with one row tubes dense structure [3] substantially limited by reason of technological risks, causes high energy losses, which heightens refractory materials consumption. A promising solution seems to be WCE with a spatial tubes structure (one row untight, two-row), which is characterized by reduced on 25-35\% heat losses due to heat insulation and heat accumulation properties of deposit slag filling [4].

(C) Timoshenko S., Nemtsev E., Gubinski M., 2021 
Known mathematical models of heat and mass transfer in the EAF workspace $[5,6]$ don't pay sufficient attention to the thermal state and energy loss in WCE in relation to foundry class furnaces.

The development of WCE with reduced heat loss and grounding on the base of mathematical model an optimal relative cooled surface of workspace, taking into account the peculiarities in foundry class EAF, are urgent.

\section{Purpose}

Work aims to improve energy efficiency and refractory savings in the EAF due to WCE design improvement.

\section{Method}

Mathematical modeling and numerical study of thermal state of WCE in foundry class EAF workspace.

\section{Main research material}

A mathematical model of heat exchange by radiation, adapted to the EAF conditions [7], was used. It deals with primary sources of radiation: surfaces of bath, arcs and electrodes. Insignificant contribution of secondary radiation, caused by dust and gas environment, was not taken into account in given comparative analysis.

Scheme of radiant heat transfer heat in AC EAF is shown in Figure1.

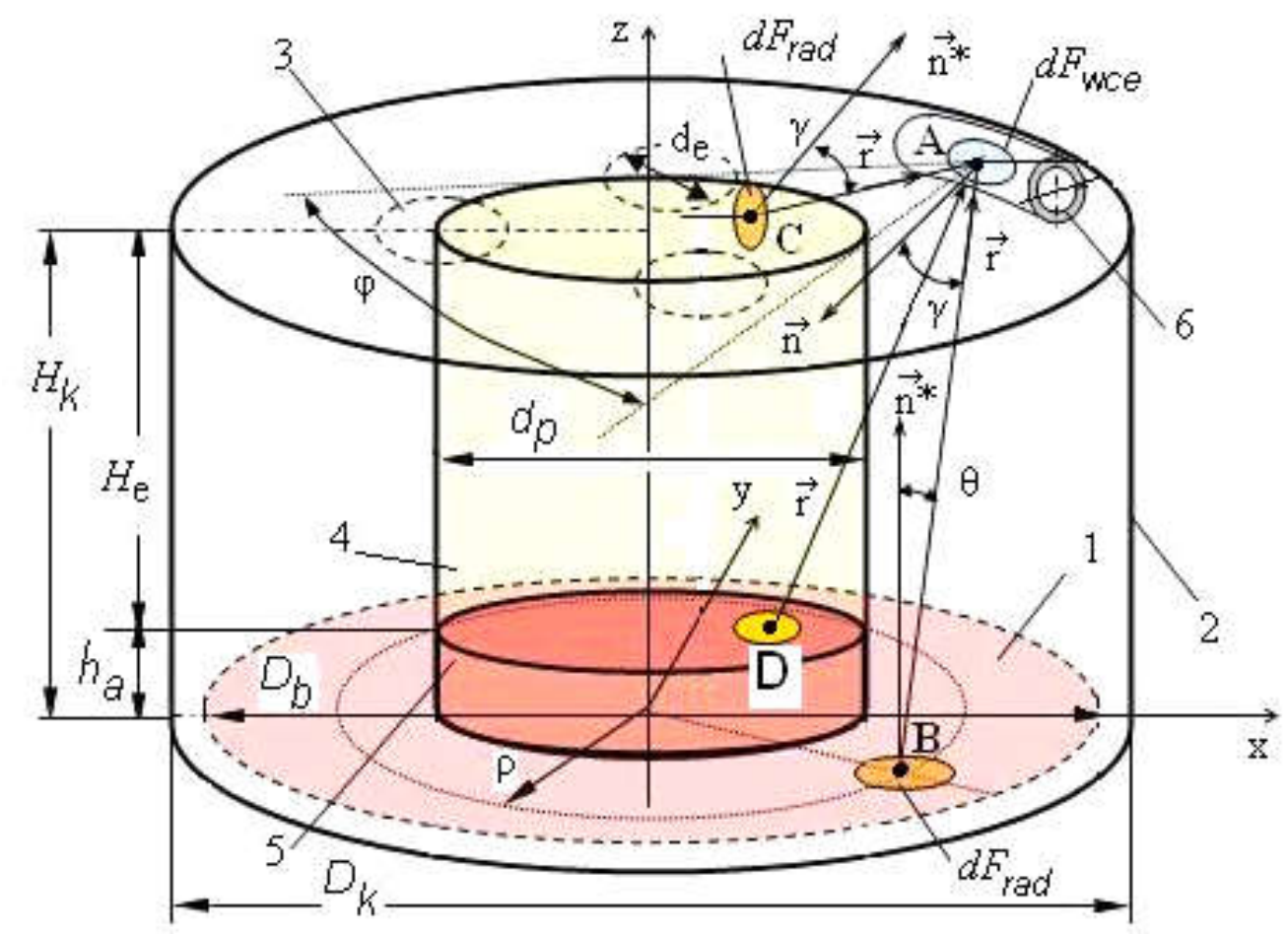

Figure 1 - Scheme of heat exchange by radiation in the EAF workspace. 1 - bath, 2 - casing,

3 - electrode, 4,5 - conditional surfaces of electrodes and arcs, respectively, 6 - WCE $\mathrm{x}, \mathrm{y}, \mathrm{z}, \varphi, \rho$ - coordinates; $\gamma, \theta$ - direction angles, $\mathrm{r}$ - radius-vector 
Radiation heat exchange workspace formed by bath with diameter $D_{b}$, casing with diameter $D_{k}$ and height $H_{k}$, electrodes with diameter $d_{e}$, height $H_{e}$ and pitch diameter $d_{p}$, arcs with length $h_{a}$. The elementary area $d F_{w c e}$ around point A, located on the tubular WCE, receives radiation from each elementary area $d F_{\text {rad }}$ of bath, electrodes and arcs around the points B, C and D, accordingly. Emitting surface of arcs and electrodes is the lateral surface of cylinders with diameter $d_{p}$. Arc length is approximated by dependence from EAF capacity $M, \mathrm{t}: \mathrm{h}_{\mathrm{a}}=0.15+0.003 \mathrm{M}, \mathrm{m}$. Temperature of the bath surface, arc and WCE is taken 1820, 3550 and $1100 \mathrm{~K}$, respectively. Temperature of electrode radiating surface $\mathrm{T}_{\mathrm{e}}=3050+19200 \zeta^{4}-48000 \zeta^{3}+40400 \zeta^{2}-13800 \zeta, \mathrm{K}$ is a function of relative height of given point of conditional cylinder surface above the bath $\zeta$, obtained basing on data [6].

The power of heat loss with cooling water by working WCE surface $F_{w c e}\left(\mathrm{~m}^{2}\right)$ with temperature $T(K)$ from radiating surface $F_{r a d}\left(\mathrm{~m}^{2}\right)$ with temperature $T_{r a d}(K)$, taking into account mutual irradiation factor, is, $\mathrm{kW}$ :

$$
P_{w c e}=\sigma \varepsilon\left(\mathrm{T}_{r a d}^{4}-\mathrm{T}^{4}\right) \iint_{F_{w c e}} \iint_{\text {rad }}\left(\frac{\cos \theta \cos \gamma}{\mathrm{r}^{2}}\right) d F_{r a d} d F_{w c e}
$$

where $\sigma$ - Stefan-Boltzmann constant, $\mathrm{kW} /\left(\mathrm{m}^{2} \mathrm{~K}^{4}\right) ; \varepsilon$ - reduced emissivity of heat exchange surfaces; $\theta, \gamma, \mathrm{r}$ - direction angles and radius vector, respectively; $k_{w c e}$ averaging coefficient of heat flux on WCE surface.

Evaluations of energy loss (1) seems convenient by approximation with multiple regression equation versus capacity of the furnace, steelmaking bath shape factor $m$ (diameter to depth ratio) and relative area of water-cooled wall surface $\beta_{w}$. In the context of 3-12-ton foundry class EAF this is, $\mathrm{kW}$ :

$$
P_{\text {wce }}=k_{\text {wce }}\left(50.78 M+46.63 m+833.75 \beta_{w}-282.31\right)
$$

The expression (2) was obtained under the condition that relative area of cooled roof surface, realized in central part, critical in terms of refractory resistance, is, from the design positions, $0.25-0.32$. Averaging coefficient of the heat flux $k_{w c e}$ depends on WCE design.

Taking into account the world [8] and domestic [4] experience in the area of energy-saving WCE, a three-row panel (Fig. 2) with a spatial structure has been developed for foundry class EAF.

Introduction of additional row of pipes contributes to increase thermal resistance to the passage of heat flux to water due to a stable slag deposition within spatial structure. 
Stationary heat exchange between EAF working space and tubular WCE, filled with thermal equilibrium layer of slag, is described by the equation:

$$
\mathrm{q}-\left(1-\varepsilon_{\text {wce }}\right) \sigma \mathrm{T}_{1}^{4}-\frac{\left(\mathrm{T}_{1}-\mathrm{T}_{2}\right)}{\left(\mathrm{b} / \lambda+\mathrm{b}_{\mathrm{g}} / \lambda_{\mathrm{g}}+1 / \alpha_{\mathrm{w}}\right)}-\alpha_{\mathrm{k}}\left(\mathrm{T}_{3}-\mathrm{T}_{0}\right)=0,
$$

where $q$ - heat flux; $\varepsilon_{\text {wce }}$ - emissivity factor; $\alpha_{\mathrm{w}}, \alpha_{\mathrm{k}}$ - heat transfer coefficient from pipe wall to water and into environment, respectively; $b, \lambda, b_{\mathrm{g}}, \lambda_{\mathrm{g}}$ - thickness and thermal conductivity of slag and pipes, respectively; $T_{1}, T_{2}, T_{3}, T_{0}$ - temperature of working surface, water, outer surface and environment, respectively.

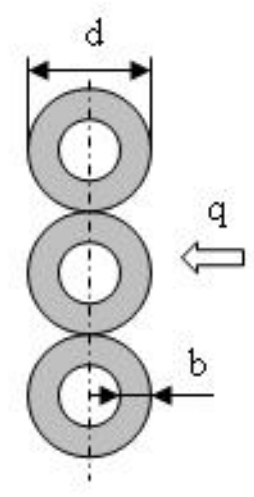

a

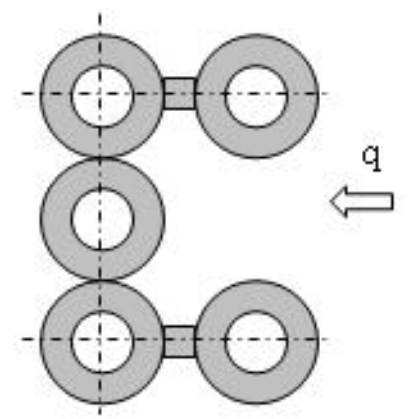

$b$

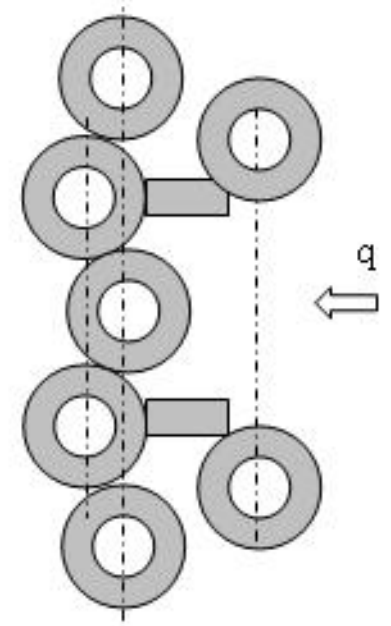

$c$

Figure 2 - WCE of traditional design with dense tubes structure (a); two-row (b) and three-row (c) panels section with spatial structure. Arrow shows actual heat flux direction. Designations are in the text

Two-dimensional problem of WCE thermal state in the EAF workspace was simulated in application package ELCUT 6.2 by the finite element method. Energy loss through outer WCE surface was neglected. Initial and boundary conditions of numerical modeling are given in Table 1.

Table 1

Initial and boundary conditions of numerical modeling

\begin{tabular}{|l|l|l|}
\hline $\begin{array}{l}\text { Name of block (B) and } \\
\text { edge (E), its number in } \\
\text { Figure 3 }\end{array}$ & $\begin{array}{l}\text { Heat conductivity }(\lambda) \text { for block. } \\
\text { Temperature }(\mathrm{T}) \text { heat transfer coefficient } \\
(\sigma, \alpha) \text {, emissivity }(\varepsilon) \text { for edge }\end{array}$ & $\begin{array}{l}\text { Dimensions, } \\
\mathrm{mm}\end{array}$ \\
\hline Slag (B1) & $\lambda=2.5 \mathrm{~W} /(\mathrm{m} \cdot \mathrm{K})[9]$ & $\mathrm{d}=60$, \\
\cline { 1 - 2 } Pipe (B2) & $\lambda=42 \mathrm{~W} /(\mathrm{m} \cdot \mathrm{K})$, steel-20 & \\
\cline { 1 - 2 } Working surface $(\mathrm{E} 1)$ & $\sigma=5.67 \cdot 10^{-8} \mathrm{~W} /\left(\mathrm{m}^{2} \cdot \mathrm{K}^{4}\right) ; \mathrm{T}=1900 \mathrm{~K} ; \varepsilon=0.7$. & \\
\hline Cooling surface $(\mathrm{E} 2)$ & $\alpha=3000 \mathrm{~W} /\left(\mathrm{m}^{2} \mathrm{~K}\right) ; \mathrm{T}=320 \mathrm{~K}$. & \\
\hline
\end{tabular}

Thermal fields in the WCE under action of heat flux $q$ for reviewed panels options are shown in Fig. 3. 


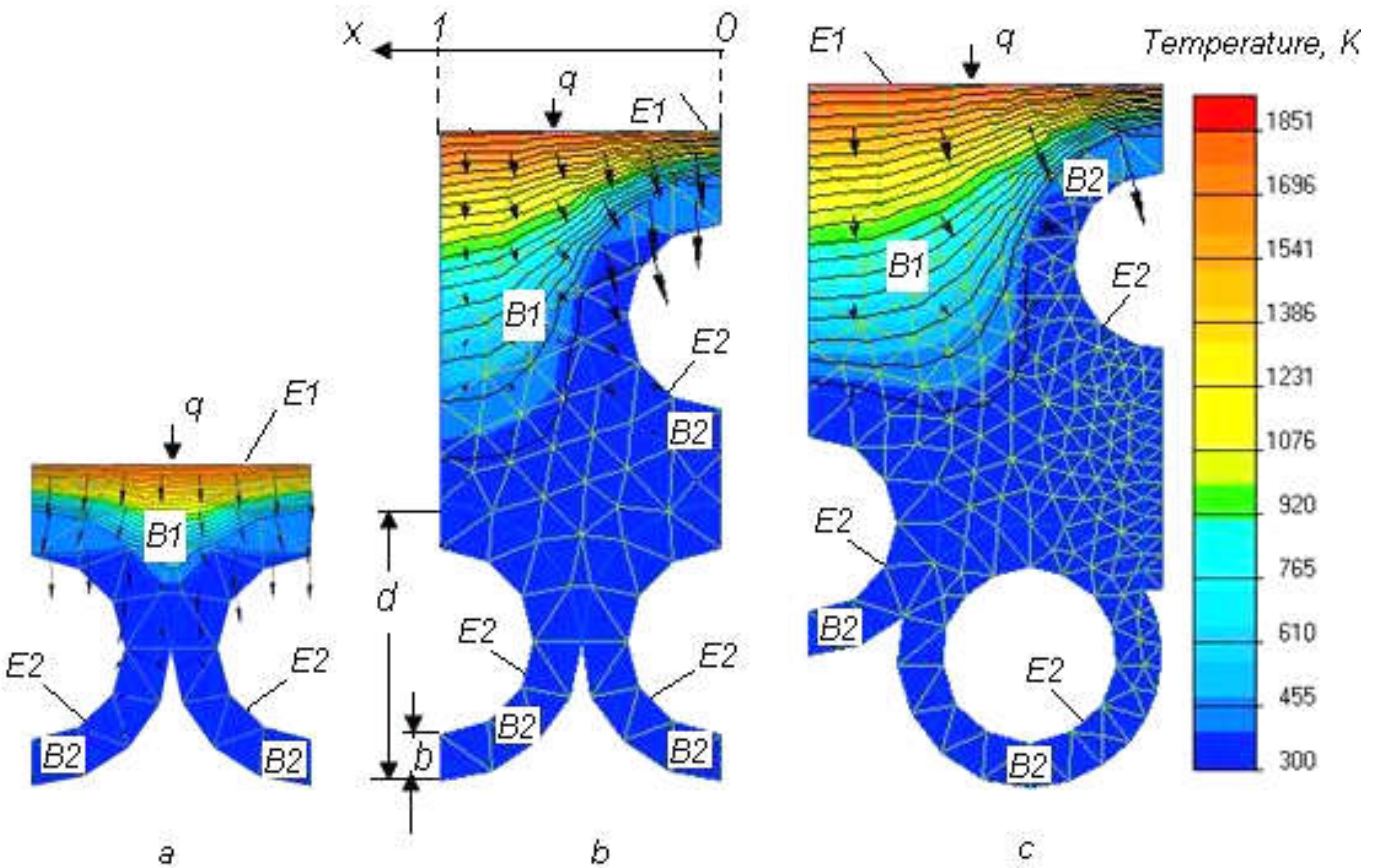

Figure 3 - Temperature fields in traditional (a), two-row (b) and proposed three-row (c) WCE. Lines are isotherms; arrows show heat flux value and direction. Designations are in Table

Integral heat loss with cooling water, evaluated by means of package on edges E2, presented in Fig. 4.

According to calculations, the transition from traditional panel to WCE with spatial two-row structure reduces heat loss with cooling water by $30 \%$, and threerow design gives additional 14\% energy savings in comparison with two-row panel.

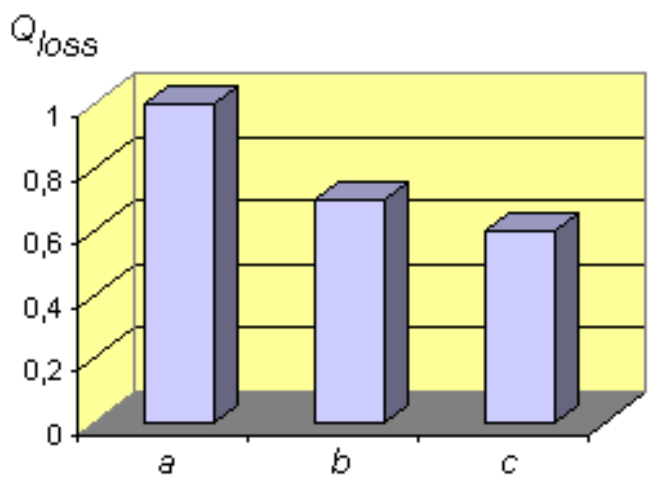

Figure 4 - Relative heat loss with cooling water $Q_{\text {loss }}$ for reviewed WCE options $a, b, c$ according to Figure 2, 3

Analysis of heat flux, passing along direction $x$ of working surface modulus (edge E1 in Fig. 3) through spatial WCE structure to cooling water, is shown in Figure 5. Pursuant to numerical modeling, spatial structure promotes increasing of panel thermal resistivity and, respectively, reduction of heat loss with cooling water. 


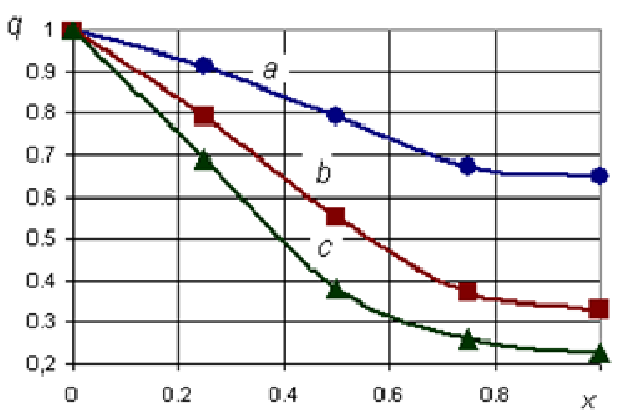

Figure5 - Relative heat flux $q$ distribution along WCE modulus relative coordinate $x$ for panels design options a, b, c according to Figure 2, 3

On the base of these data, the values of averaging coefficient of heat flux on WCE surface for panel options were obtained, in a first approximation, as half-sum of the boundary relative heat fluxes in considered modulus. For traditional, two- and three-row panels $k_{w c e}$ is $0.82,0.67$ and 0.61 , respectively.

The energy balance of refining period in 3-12-t EAF is made for next conditions: melting of structural steel; forced bath inert gas stirring; reduction of bath shape factor from traditional 4.5 to 2.5 ; combined roof with central watercooled part with relative area $0.25-0.32$. For proposed three-row WCE an average relative cooled surface of walls in 3-12-t EAF can reach 0.5-0.6. Given value of $\beta_{w}$ ensures reduction in refractory consumption up to $25-30 \%$.

\section{Conclusions}

Three-row water-cooled wall panels with a spatial structure are elaborated, which provide a decrease in heat loss by $14 \%$, in comparison with two-row ones, and by $40 \%$ in comparison with traditional one-row dense structure WCE.

Estimates of optimal relative cooled surface of the EAF working space, providing refractory savings up to $25-30 \%$, are substantiated.

\section{REFERENCES}

1. Biswas, S., Peaslee, K., Lekakh, S. (2012). Melting energy efficiency in steel foundries. AFS Transactions 2012 @ American Foundry Society, Schaumburg, Il. USA, 449-456.

2. Mironov, Yu.M., Petrov, V.G. (2010). Thermal losses and power efficiency of arc steelmaking furnaces. Metally (Russian Metallurgy), 12, 1141-1144.

3. Toulouevski, Yu., Zinurov, I. (2010) Innovation in Electric Arc Furnaces. Scientific Basis for Selection. Berlin (Germany): Springer-Verlag. 258 p.

4. Timoshenko, S..M., Doroshenko, A..V., Dyadkov, B.P., Tischenko, P.I., Onischenko, S.P. (2018). Energoeffektivnyye resheniya pri modernizatsii malotonnazhnykh dugovykh staleplavil'nykh pechey liteynogo klassa (Energy-efficient solutions for the modernization of low-tonnage arc furnaces of foundry class). Metall i lyt'e Ukrayny (Metal and casting of Ukraine), 3-4, 34-40.

5. Logar, V., Dovžan, D., Škrjanc, I. (2012). Modeling and validation of an electric arc furnace. ISIJ International, vol. 52, 3, 402-423.

6. Gruber, J-C., Echterhof, T., Pfeifer, H. (2016). Investigation on the Influence of the Arc Region on Heat and Mass Transport in an EAF Freeboard using Numerical Modeling. Steel research international, vol. 87, no.1, 15-28. DOI: 10.1002/srin.201400513.

7. Timoshenko, S.N. (2016). Computer modeling bath geometry to improve energy efficiency of electric arc furnace. System Technologies. Regional interuniversity collection of scientific works. Dnipro: NMetAU-IVK Systemni tekhnolohiyi, 3, 33-39. 
8. Patent US 5772430. F27D 9/00. M. Pavlicevic, G. Gensini, A. Poloni, R. Sellan (1996). Cooling device with panels for electric arc furnaces. Danieli \&Co Off. Mec., Spa (Italy).

9. Kruger, K., Ehrbar, A., Timm, K. (1998). Schlackenanbackungen und thermische Verluste eines Drehstrofens. Stahl und Eisen, 9 (118), 63-67.

Received 11.01.2021. Accepted 25.01.2021.

UDC: 621.365 .22

S. Timoshenko, E. Nemtsev, M. Gubinski

\section{ENERGY EFFICIENT WATER-COOLED ELEMENTS FOR FOUNDRY CLASS ELECTRIC ARC STEELMAKING FURNACES.}

Analysis of recent research and publications. Low energy efficiency of foundry class electric arc steelmaking furnaces (EAF) mainly is caused by heat loss in massive refractory lining during forced downtime. A low-power transformer doesn't allow, in the conditions of classical technology, practice of traditional water-cooled elements in order to replace partially the lining, what determines increased refractory consumption. Known mathematical models of heat and mass transfer in the EAF working space don't pay sufficient attention to the features of thermal state and energy loss in water-cooled elements in relation to foundry class furnaces.

Purpose. Work aims to improve energy efficiency and refractory savings in foundry class EAF due to water-cooled elements design improvement.

Method. Work is based on numerical modeling of heat exchange by radiation in the working space of the EAF and thermal state of water-cooled elements with spatial structure.

Research findings. On the base of radiation heat exchange study, a multiple regression equation for power of heat loss with cooling water was obtained, taking into account capacity of the furnace, steelmaking bath shape factor (diameter to depth ratio), duration of technological period of the heat and averaging coefficient of heat flux through working surface of water-cooled element. For traditional one-row, two- and elaborated three-row panels averaging coefficient is $0.82,0.67$ and 0.61 , respectively.

Practical significance. Three-row water-cooled wall panels with a spatial structure are elaborated, which provide a decrease in heat loss with cooling water by $14 \%$, in comparison with two-row ones and by $40 \%$ in comparison with traditional one-row panels with dense structure. Estimates of optimal relative cooled surface for 3-12-ton EAF working space, providing refractory savings up to $25-30 \%$ due to three-row water-cooled panels installation, are substantiated.

Keywords: foundry class electric arc furnace, water-cooled elements, energy efficiency.

УДК 621.365.22

С.М. Тімошенко, Е.М. Нємцев, М.В. Губинський

\section{ЕНЕРГОЕФЕКТИВНІ ВОДООХОЛОДЖУВАНІ ЕЛЕМЕНТИ ДУГОВИХ СТАЛЕПЛАВИЛЬНИХ ПЕЧЕЙ ЛИВАРНОГО КЛАСУ}

Аналіз останніх досліджень та публікацій. Низька енергоефективність сталеплавильних електродугових печей класу ливарного класу (ДСП) головним чином обумовлена втратами тепла у масивних вогнетривких футеровках під час вимушеного простою. Трансформатор малої потужності не дозволяє в умовах класичної технології 
застосовувати традиційні елементи з водяним охолодженням, щоб частково замінити футеровку, що обумовлює збільшення витрат вогнетривких матеріалів. Відомі математичні моделі тепло- та масопереносу в робочому просторі ДСП не приділяють достатньої уваги особливостям теплового стану і втратам енергії у водоохолоджуваних елементах, коли мова йде про печі ливарного класу.

Мета. Робота спрямована на підвищення енергоефективності та економії вогнетривів у ДСП ливарного класу за рахунок покращення конструкції водоохолоджуваних елементів.

Метод. Робота заснована на чисельному моделюванні теплообміну випромінюванням у робочому просторі ДСП і теплового стану водоохолоджуваних елементів просторової структури.

Результати досліджень. На основі досліджень радіаційного теплообміну було отримано рівняння множинної регресії для потужності теплових втрат 3 охолоджуваною водою, що враховує потужність печі, коефіцієнт форми сталеплавильної ванни (відношення діаметра до глибини), тривалість технологічного періоду нагріву й усереднюючий коефіцієнт теплового потоку через робочу поверхню водоохолоджуваного елемента. Для традиційних однорядних, дворядних і складних трирядних панелей коефіцієнт усереднення становить 0,82, 0,67 і 0,61 відповідно.

Практичне значення. Розроблено трирядні водоохолоджувані стінові панелі 3 просторовою структурою, що забезпечує зниження теплових втрат з охолоджуваною водою на $14 \%$ у порівнянні з дворядними і на 40\% у порівнянні з традиційними однорядними панелями 3 щільною структурою. Отримано оцінку оптимальної відносної охолоджуваної поверхні робочого простору ДСП 3-12 т, що забезпечує економію вогнетриву до $25-30 \%$ за рахунок встановлення трирядних водоохолоджуваних панелей.

Ключові слова: електродугова піч ливарного класу, водоохолоджувані елементи, енергоефективність.

Тімошенко Сергій Миколайович - д.т.н., с.н.с., кафедра електричної інженерії, ДВНЗ «Донецький національний технічний університет».

Нємщев Едуард Миколайович - кафедра електричної інженерії, ДВНЗ «Донецький національний технічний університет».

Губинський Михайло Володимирович - д.т.н., проф., кафедра промислової теплоенергетики, Національна металургійна академія України.

Тимошенко Сергей Николаевич - д.т.н., с.н.с., кафедра электрической инженерии ГВУЗ «Донецкий национальный технический университет».

Немцев Эдуард Николаевич - кафедра электрической инженерии, ГВУЗ «Донецкий национальный технический университет».

Губинский Михаил Владимирович - д.т.н., проф., кафедра промышленной теплоенергетики, Национальная металлургическая академия Украины.

Timoshenko Sergii - Dr. of Sci., Donetsk National Technical University, professor.

Nemtsev Eduard - Senior Instructor, Donetsk National Technical University.

Gubinskij Mikhail - doctor of engineering's sciences, professor, The National Metallurgical Academy of Ukraine. 